\title{
Effect of Paclobutrazol Treatment on Some Leaf Physiological and Biochemical Characteristics of Rejuvenated Coffee (Coffea arabica L.) Trees
}

\author{
Arsenio D. Ramos and Antonio L. Acedo, Jr. \\ Department of Horticulture, College of Agriculture and Food Science, Visayas State \\ University, Baybay City, Leyte 6521-A, Philippines
}

\section{ABSTRACT}

Rejuvenation pruning has been proven effective in bringing back vigor and productivity of old coffee trees. The effectiveness of the present rejuvenation techniques however could be probably enhanced by the application of tree growth regulators with known reinvigorating or tree health enhancing effect such as Paclobutrazol but has not been tried so far. The present study aimed to evaluate some physiological and biochemical responses of the rejuvenated coffee trees to timing and level of PBZ application prior to cutting.

Plants applied with PBZ 2 months prior to pruning had higher leaf internal $\mathrm{CO}_{2}$ concentration compared to those applied 1 month prior to pruning. Net photosynthesis, transpiration rate, PAR/LAI, chlorophyll content, and leaf N, P, K, Ca and Mg contents did not differ with time of PBZ treatment. Application of 0.5-1.0 g a.i. PBZ per meter canopy span significantly increased transpiration rate, internal $\mathrm{CO}_{2}$ concentration and chlorophyll content but did not affect the rate of photosynthesis, PAR/LAI, leaf $\mathrm{N}, \mathrm{P}, \mathrm{K}, \mathrm{Ca}$ and Mg contents.

Keywords: rejuvenation pruning, Paclobutrazol, growth retardant, physiological and biochemical responses.

\section{INTRODUCTION}

Paclobutrazol (PBZ) [2RS, 3RS)-1-4 (-chlorophenyl)-4,4-dimethyl-2-1, 2, 4-triazol-1-yl-penten-3-ol], a member of the triazole group with both fungicidal and plant growth regulatory effects is known to have reinvigorating effect on plants by influencing or altering crop physiology. Among the reported effects of PBZ application on plant physiological processes include increased rate of photosynthesis (Sankhla et al. 1986; Zhou and Xi, 1993; Berova and Zlatev, 2000; Dalziel and Lawrence, 1984),increased stomatal conductance (Qi et al. 2006), delayed onset of leaf senescence (Proietti et al. 1999) and improve water relations due to reduced transpiration rate and reduced leaf surface area (Fletcher and Nath, 1984).

Correspondence: A.D. Ramos Address: Department of Horticulture, College of Agriculture and Food Science, Visayas State University, Baybay City, Leyte 6521-A, Philippines. Tel No.: (053) 335-2628; Email:adr_senio@yahoo.com DOI: $10.32945 /$ atr3825.2016 
On the other hand, increased leaf tissue chlorophyll content (Sopher et al. 1999; Berova and Zlatev, 2000; Sebastian et al. 2002), increased soluble protein contents in leaves (Wang et al. 1985; Sopher et al. 1999), increased leaf mineral contents (Yelenosky et al. 1995; Yeshitela, 2004) and decreased shoot GA contents (Rademacher, 1991; Protacio, 2000)were among the reported plant biochemical responses to PBZ application.

In coffee, rejuvenation pruning was developed as a cultural management strategy to bring back old rundown trees to acceptable production level, with yield improvement as the ultimate benefit (Canell, 1983; Cabangbang, 1988; CEMARRDEC, 1990; Jativa, 1990; Netsere et al. 2006). An effective rejuvenation system should promote faster development and production of new shoot system which is required for early bearing. The different aspects of the rejuvenation process including specific cutting method (Netsere et al. 2006, Pugoy, 1991), fertilizer application (Pugoy, 1991; Bacasno, 2002),mulching (Bacasno, 2002) and shading (http://abstracts.aspb.org/pb2003/public/P72/1437) had been already studied. In the Philippines, rejuvenation techniques for old coffee trees had been recommended (Cabangbang, 1990). Common among the different rejuvenation technologies include specific pruning height, rate of fertilizer application, sprout selection and training technique. Application of tree growth regulators with known reinvigorating or reconditioning effect to enhance tree health like Paclobutrazol could probably further improve the effectiveness of the existing rejuvenation technologies.

To our knowledge, there has been no study determining the effects of pre-rejuvenation application of PBZ on the performance of rejuvenated coffee trees. Specifically, the study aimed to evaluate some physiological and biochemical responses of the rejuvenated coffee trees to timing and level of PBZ application prior to cutting.

\section{MATERIALS AND METHODS}

\section{The Experimental Trees}

Thirty (30) year old non-productive coffee trees planted at the Coffee Project of the Department of Horticulture, College of Agriculture and Food Science, Visayas State University, Visca, Baybay City, Leyte, were used. The trees were planted at $3 \mathrm{~m} \times 3 \mathrm{~m}$ using triangular planting system and were under $30-35 \%$ shade provided by Thailand acacia (Acasiaspectabilis A. Cunn. ex Benth) trees. The trees had an average height of $6.60 \mathrm{~m}$, base girth circumference of $65.52 \mathrm{~cm}$ and canopy span of 4.20 meters. The trees had multiple vertical stems due to non-removal of water sprouts. The lateral branches found mostly at upper part of the verticals were overcrowded, had already overlapped with lateral branches of the neighboring trees, and had only very few fruits mostly located near the tip of the branches. Trees with more or less the same stand (height and spread) were selected as experimental samples. 


\section{Experimental Design and Treatments}

The experiment was laid out in factorial randomized complete block design (RCBD) with three replications, each replicate with 3 sample trees. The time of Paclobutrazol application $\left(\mathrm{T}_{1}-1\right.$ month before cutting and $\mathrm{T}_{2}-2$ months before cutting) was assigned as Factor A and the three levels of PBZ application namely: L1 - 0 (water, control), $\mathrm{L}_{2}-0.5 \mathrm{~g}$.a.i.PBZ /meter span of canopy or $2 \mathrm{ml}$ Cultar/meter canopy span and $\mathrm{L}_{3}$ - 1.0g.a.i.PBZ/meter span of canopy or $4 \mathrm{ml}$ Cultar/meter canopy span as Factor B.

For $\mathrm{L}_{2}$ and $\mathrm{L}_{3}$ trees, a total of 8 and $16 \mathrm{ml}$ Cultar per tree, respectively, was applied because their average canopy span was $4 \mathrm{~m}$.

\section{Paclobutrazol Application}

Commercial grade PBZ with 25\% active ingredient (a.i.) (Trade name 'Cultar 25 SC', Syngenta UK Ltd.) was used. The required amount of Cultar was dissolved in one gallon water and was applied following the collar drench method (Figure 1). Furrows were made around the tree $30 \mathrm{~cm}$ away from the base and the PBZ solution was applied evenly along the furrows. For the untreated control, one gallon plain tap water was applied per plant.
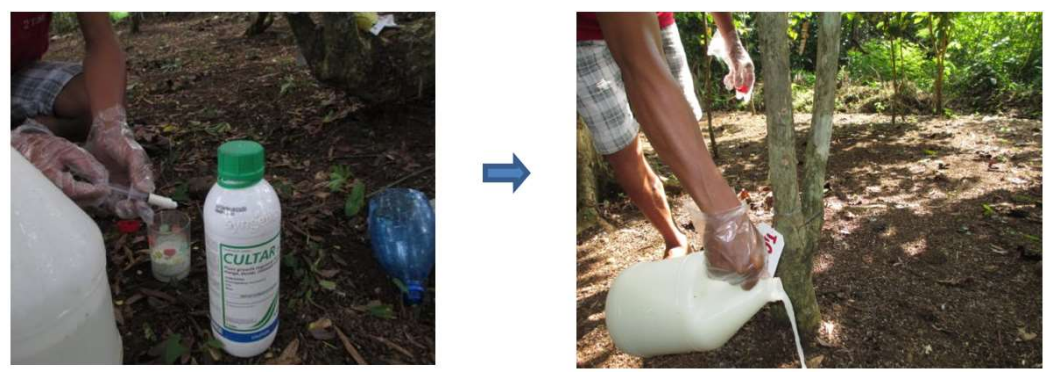

Figure1. PBZ formulation and application by collar drenching technique

\section{Rejuvenation Pruning}

The procedures in heading back or rejuvenation pruning recommended by Cabangbang (1990) was followed. The main vertical stem was cut following a slanting cut one foot from the ground using sharp pruning saw. The cut surface was allowed to dry for 5 days and then was painted with coal tar (Figure 2).

\section{Maintenance of the Experimental Trees}

The rejuvenated plants were applied with $250 \mathrm{~g}$ complete fertilizer (14-14-14) per plant one month after pruning following the holing method ( $\mathrm{six} 5-\mathrm{cm}$ deep holes around the stump at a distance of $50 \mathrm{~cm}$ ).The base of experimental plants were ring weeded and mulched with $5 \mathrm{~cm}$ thick rice hull. The areas in between rows were regularly underbrushed at three 
months interval. When the sprouts were about $10 \mathrm{~cm}$ tall, preliminary sprout selection was done by removing the weak sprouts and retaining the 3 most vigorous sprouts per stump. When the retained sprouts were about $30 \mathrm{~cm}$ tall, the 2 weakest sprouts were removed retaining the most vigorous sprout per stump. Three shoots (1per stump) were allowed to grow per tree for 10 months (Figure 3). Subsequent shoots that emerged were regularly removed.

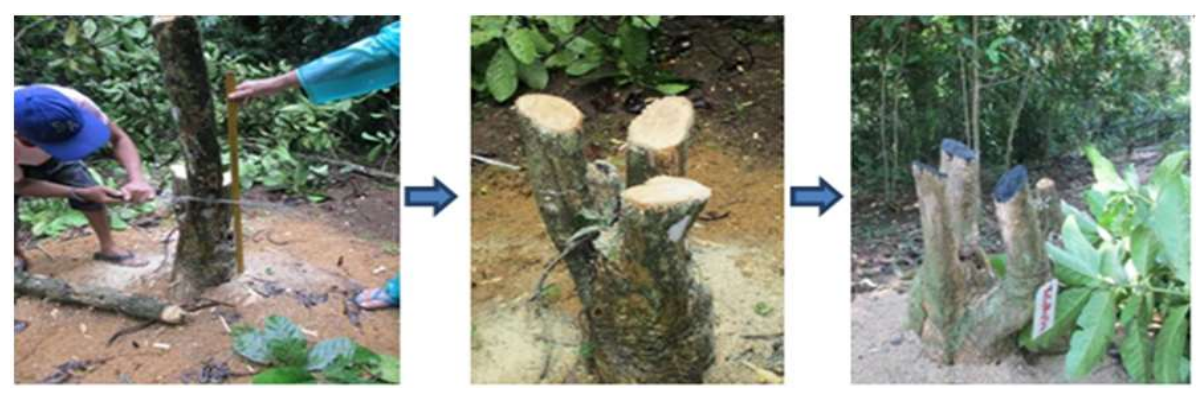

Figure 2. The rejuvenation pruning technique followed in rejuvenating old coffee trees

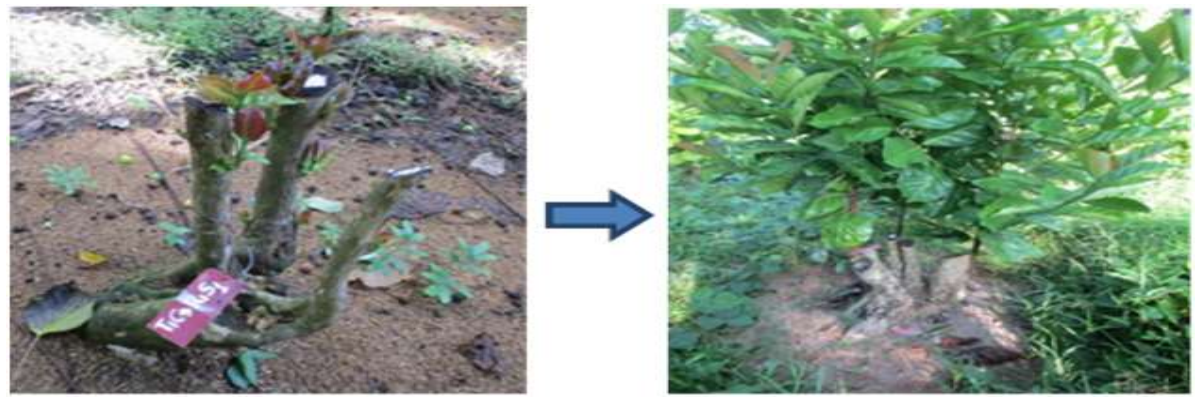

Figure 3. The selection of sprouts to establish plants with 3 shoots (1 shoot per stump)

\section{Measurement of Parameters}

Using the $4^{\text {th }}$ pair from the youngest open leaf of the second pair of lateral branches from the base as index leaf, photosynthetic rate, transpiration rate and internal $\mathrm{CO}_{2}$ concentration were monitored using a Portable Photosynthesis System LI-6400 XT (LI-COR Biosciences Inc. 4421 Superior St. Lincoln, Nebraska 68504)while PAR/LAI using Digital Plant Canopy Imager CI-110 (CID Bio Science 1554 NE $3^{\text {rd }}$ Ave. Camas, WA USA) after 8 and 10 months from pruning. Leaf chlorophyll content was quantified using Minolta Chlorophyll Meter SPAD-502 (Minolta Co. Ltd. Japan). The leaves used in chlorophyll analysis were collected in the morning. The leaf samples were placed in properly labeled paper bag and brought to the Crop Physiology Laboratory of the Department of Horticulture, cleaned of dust and then oven-dried at $60-65^{\circ} \mathrm{C}$ for 5 days using forced draft oven. The dried samples were ground using Willey mill, placed in properly labeled paper bags and were submitted to the Central 
Analytical Laboratory of the Philippine Rootcrop Research and Training Center for determination of N, P, K, Mg and Ca contents.

\section{Statistical Analysis}

Data were analyzed by performing analysis of variance (ANOVA) and treatment means were compared by Least Significant Difference (LSD) test at 5\% level of significance using the STAR, version 2.0.1 2014 Biometrics and Breeding Informatics, PBGB Division International Rice Research Institute, Los Banos, Laguna.

\section{RESULTS AND DISCUSSION}

\section{Leaf Physiological Responses to PBZ}

Time of PBZ application significantly influenced internal $\mathrm{CO}_{2}$ concentration 10 months after cutting but not the transpiration rate, net photosynthesis and PAR/LAI 8 and 10 months after cutting (Table 1). Regardless of level of PBZ application, leaves of plants applied with PBZ 2 months before cutting had significantly higher internal $\mathrm{CO}_{2}$ concentration than leaves from plants applied with PBZ 1 month before cutting. The high internal $\mathrm{CO}_{2}$ concentration in leaves among plants treated with PBZ 2 months before cutting over those applied with PBZ 1 month before cutting could be probably attributed to the effect of PBZ in improving plant water relations resulting from production of more fine roots (Ramos and Acedo, 2014 ) thereby increasing water absorption. Improved water relations also improved opening of stomata which promote gas exchange that raised leaf internal $\mathrm{CO}_{2}$ concentration.

Significant effect of PBZ concentration was also obtained for transpiration rate and leaf internal $\mathrm{CO}_{2}$ concentration (Table 1). Leaves of plants applied with 1.0g.a.i. PBZ/meter canopy span had significantly higher transpiration rate than those applied with 0.5 g.a.i. PBZ/meter canopy span and the non-PBZ treated control sampled 8 months after cutting. After 10 months from cutting, the PBZ and the non-PBZ treated control had comparable leaf transpiration rate.

Furthermore, plants applied with 0.5 and 1.0 ga.i. PBZ per meter canopy span had higher leaf internal $\mathrm{CO}_{2}$ concentrations than leaves of the non-PBZ treated plants. The improved plant water relations among PBZtreated plants explained earlier may account for their higher leaf internal $\mathrm{CO}_{2}$ concentrations over the non-PBZ-treated control plants.

PAR/LAI which is the measure of the fraction of absorbed photosynthetically active radiation (PAR) that the coffee plant canopy absorbed was not significantly affected by PBZ application. The coffee plant LAI was not also significantly altered by PBZ application (Ramos and Acedo, 2014). 
Table 1. Effect of timing and level of PBZ application on some leaf physiological processes of the rejuvenated coffee trees

\begin{tabular}{|c|c|c|c|c|c|c|c|}
\hline \multirow{3}{*}{ Treatments } & \multicolumn{4}{|c|}{$\begin{array}{l}\text { Photosynthesis } \\
\begin{array}{cc}\left(\mu \mathrm{mol} \mathrm{CO} \mathrm{CO}_{2} \mathrm{~m}^{-2} \mathrm{~s}^{-}\right. & \text {Rate (mmolion } \\
1) & \left.\mathrm{H}_{2} \mathrm{O} \mathrm{m}^{-2} \mathrm{sec}^{-1}\right)\end{array} \\
\end{array}$} & \multicolumn{2}{|c|}{$\begin{array}{c}\text { Internal } \mathrm{CO}_{2} \\
\text { Concentration } \\
\left(\mu \mathrm{mol} \mathrm{CO} \mathrm{m}^{-2} \mathrm{~s}^{-1}\right) \\
\end{array}$} & $\begin{array}{c}\text { PAR/LAI } \\
\left(\mu \mathrm{molm}^{2} \mathrm{~s}\right)\end{array}$ \\
\hline & \multicolumn{2}{|c|}{$\begin{array}{l}\text { Month After } \\
\text { Cutting }\end{array}$} & \multicolumn{2}{|c|}{$\begin{array}{l}\text { Month After } \\
\text { Cutting }\end{array}$} & \multicolumn{2}{|c|}{$\begin{array}{c}\text { Month After } \\
\text { Cutting }\end{array}$} & \multirow[t]{2}{*}{$10^{\text {th }}$ Month } \\
\hline & 8 & 10 & 8 & 10 & 8 & 10 & \\
\hline \multicolumn{8}{|l|}{ Time of PBZ Application } \\
\hline 1 month before cutting & 13.53 & 16.03 & 6.89 & 7.05 & 155.92 & $183.91 b$ & 3.07 \\
\hline $\begin{array}{l}2 \text { months before } \\
\text { cutting }\end{array}$ & 14.08 & 15.36 & 6.74 & 7.27 & 161.48 & $204.54 a$ & 2.48 \\
\hline \multicolumn{8}{|l|}{ PBZ Concentration } \\
\hline 0 (water, control) & 13.34 & 15.18 & $6.39 b$ & 6.84 & 151.52 & $174.79 b$ & 3.06 \\
\hline $\begin{array}{l}0.5 \mathrm{~g} \text {.a.i. PBZ } / \mathrm{m} \text { canopy } \\
\text { span }\end{array}$ & 13.50 & 15.28 & $6.25 b$ & 7.26 & 168.06 & $214.10 \mathrm{a}$ & 2.56 \\
\hline $\begin{array}{l}\text { 1.0g.a.i. PBZ/m canopy } \\
\text { span }\end{array}$ & 14.57 & 16.62 & $7.79 a$ & 7.38 & 178.84 & $193.79 \mathrm{ab}$ & 2.58 \\
\hline $\mathrm{CV}(\%)$ & 13.86 & 9.50 & 14.17 & 11.44 & 13.02 & 9.66 & 30.28 \\
\hline
\end{tabular}

Mean separation within columns by LSD, $5 \%$.

Leaf Biochemical Responses to PBZ

PBZ application (0.5 and $1.0 \mathrm{~g}$ a.i./m canopy span) significantly increased the leaf chlorophyll content 10 months after cutting (Table 2). These results corroborate earlier findings. Higher leaf chlorophyll contents resulting from PBZ application were found in maize seedlings (Sopher et al. 1999), tomato (Berova and Zlatev, 2000) and Dianthus (Sebastian et al. 2002). Berova and Zlatev (2000) and Sopher et al. (1999) attributed PBZ-induced increase in chlorophyll content to the ability of PBZ to increase the level of endogenous cytokinin which is known to stimulate chlorophyll biosynthesis and/or reduced chlorophyll catabolism. Chaney (2005) added that PBZ has enhancing effect on the production of phytol which is an essential part of the chlorophyll molecule.

PBZ had no marked influence on total N, P, K, Ca and Mg contents of the leaf after 10 months from pruning (Table 2). Earlier, lack of PBZ effect on leaf macronutrient status was also obtained in apple (Wieland and Wample, 1985) and mango (Leal et al. 2000; Yeshitela et al. 2004).

\section{CONCLUSION}

PBZ treatment significantly enhanced some physiological parameters of the coffee leaf evaluated in the study particularly the internal $\mathrm{CO}_{2}$ concentration and transpiration rate but did not influenced net photosynthesis and PAR/LAI. The growth retardant treatment also significantly increased the leaf chlorophyll content but had no mark effect on the leaf total N, P, K, Ca and Mg contents. 
Table 2. Effect of timing and level of PBZ application on chlorophyll and leaf nutrient contents of rejuvenated coffee plants 10 months from cutting

\begin{tabular}{lllllll}
\hline \multicolumn{1}{c}{ Treatments } & $\begin{array}{l}\text { Chlorophyll } \\
\text { Content } \\
\text { (SPAD } \\
\text { reading) }\end{array}$ & $\begin{array}{c}\text { Total } \\
\mathrm{N} \\
(\%)\end{array}$ & $\begin{array}{l}\text { Total P } \\
(\mathrm{mg} / \mathrm{kg})\end{array}$ & $\begin{array}{c}\text { Total K } \\
(\mathrm{g} / \mathrm{kg})\end{array}$ & $\begin{array}{c}\text { Total } \\
\mathrm{Ca} \\
(\mathrm{g} / \mathrm{kg})\end{array}$ & $\begin{array}{l}\text { Total } \\
\mathrm{Mg} \\
(\mathrm{g} / \mathrm{kg})\end{array}$ \\
\hline $\begin{array}{l}\text { Time of PBZ Application } \\
\quad \text { 1 month before } \\
\text { cutting }\end{array}$ & 67.35 & 1.92 & 287.57 & 14.44 & 15.42 & 2.74 \\
$\quad \begin{array}{l}\text { 2 months before } \\
\text { cutting }\end{array}$ & 66.95 & 1.99 & 288.52 & 14.43 & 15.02 & 2.81 \\
$\begin{array}{l}\text { PBZ Concentration } \\
\quad \text { (water, control) }\end{array}$ & $62.35 \mathrm{~b}$ & 2.00 & 287.74 & 14.27 & 15.28 & 2.80 \\
$\quad \begin{array}{l}\text { 0.5g.a.i. PBZ/m canopy } \\
\text { span }\end{array}$ & $67.75 \mathrm{a}$ & 1.98 & 289.12 & 14.61 & 15.70 & 2.79 \\
$\begin{array}{l}\text { 1.0g.a.i. PBZ/m canopy } \\
\text { span }\end{array}$ & $70.91 \mathrm{a}$ & 1.97 & 287.26 & 14.43 & 14.67 & 2.75 \\
\hline CV (\%) & 4.87 & 8.56 & 3.70 & 12.86 & 10.24 & 6.46 \\
\hline
\end{tabular}

Mean separation within columns by LSD, $5 \%$.

\section{ACKNOWLEDGMENT}

The authors would like to acknowledge the Agricultural Training Institute- Department of Agriculture through its capability building program the Expanded Human Resource Development Program for the dissertation grant and the ACIAR- Forestry Project staff Dr. Nestor Gregorio, Dr. Angela A. Ferraren and Dr. Arturo E. Pasa for allowing the use of the photosynthesis meter and canopy analyzer free of charge.

\section{REFERENCES}

BACASNO, W. C. 2002. Effects of mulching and fertilizer application on the early growth performance of rejuvenated coffee trees (Coffeaarabica L). Undergraduate BSA Thesis.Leyte State University, Visca, Baybay, Leyte.

BEROVA, M and Z. ZLATEV. 2000. Physiological response and yield of paclobutrazol treated tomato (Lycopersiconesculentum Mill). Plant Growth Regulator 30(2)117-123

CABANGBANG, R. P. 1988. NPK fertilizer requirements of rejuvenated coffee plants. Southern Mindanao Agricultural Research Center Monitor. Kabacan, North Cotabato.

CABANGBANG, R. P. 1990. Coffee rejuvenation in the Philippines. Technol. J. 12(3):1-16.

CANELL, M.G. 1983. Plant Management in Agroforestry: Manipulation of Trees/Population Densities and Mixture of Trees and Herbaceous Crops. Plant Res in Agroforestry.ICRAF.P.O.Box300667 Nairobe, Kenya.pp, 455-487.

CEMARRDEC. 1990. MgaTanong at SagotUkolsaPagpapabatangKape. University of Southern Mindanao.Kabakan, Cotabato. 12p.

CHANEY, W.R. 2005. Growth retardants: A promising tool for managing urban trees. Purdue University Extension. FNR-252-W. 
DALZIEL, J. and D.K. LAWRENCE.1984. Biochemical and biological effects of kaurene oxidase inhibitors such as paclobutrazol. In: Biochemical aspects of synthetic and naturally occurring plant growth regulators. British Plant Growth Regulator Group Monograph.11:43-57.

FLETCHER, R.A. and V. NATH. 1984. Triadirnefon reduces transpiration and increases yield in water stressed plants. Physiol. Plant. 62:422-426.

JATIVA, M.1990. Rehabilitation of coffee trees by stumping in the Amazon Region, Ecuador. Boletin Divulgativo INIAP 1990 No. 207.9p.

LEAL, F., E.SERGENT,and M. ANEZ. 2000. Effect of some plant growth regulators on leaves content of macronutrient in mango "Haden". Acta Hort. (509): 631-634.

NETSERE, A.,T.SHIMBER,T.KUFA,E.TAYE,and W. GEBRESELASSIE. 2006. Yield response of forest arabica coffee to ridges and rejuvenation methods. Presented in the21st International Conference on Coffee Science, September 11-15, 2006, Montpellier, France. Pp. 1101-1105.

PROIETTI, P., PALLIOTI, P., AMTOGNOZZI, E., FERRANTE, F AND J.D. QUINLAN. 1999. Patterns of anatomy differentiation, growth and physiological activity following paclobutrazol application in chestnut. Acta Hort. 463:177-184

PUGOY, N.P.1991. Initial vegetative regeneration of rejuvenated coffee as influenced by cutting height and NPK fertilizer combination scheme. Undergraduate BSA Thesis.ViSCA, Baybay, Leyte.

PROTACIO, C.M. 2000. A model for potassium nitrate induced flowering in mango. Acta Hort. 509:545-552

QI, Y., HILTON, T.K., W.R. CHANEY, and Y. XIAO. 2006. Paclobutrazol tree growth regulator affects physiology and morphology of sweetgum and cherrybark oak. Presented in 14th Biennial Association of Research Directors' Symposium, April 1-5, 2006, Atlanta, Georgia, USA

RADEMACHER, W. 1991. Biochemical effects of plant growth retardants. In Plant Biochemical Regulators.Edited by H. W. Grossman.Macel Dekker, Inc.,New York. pp 169-200.

RAMOS, A.D. AND A.L. ACEDO, JR. 2013. Morphological effects of paclobutrazol on the re-growth of rejuvenated coffee (Coffea arabicaL.) trees. Science and Humanities Journal.10:36-53.

SANKHLA, N., T.D. DAVIS,V.D.JOLLEY,and A. UPADHYAYA. 1986. Effect of paclobutrazol on the development of iron chlorosis in soybeans. J. Plant Nutr. 9:923-934.

SEBASTIAN, B.G., G.ALBERTO, A.C. EMELIO, A.F. JOSE, and A.F. JUAN. 2002. Growth development and color response of potted Dianthus caryophyllus cv. Mandarin to paclobutrazol treatment. Sci. Hort. 1767, 1-7.

SOPHER, C.R., M.KROL, N.P.A. HUNER, A.E. MOORE,and R.S. FLETCHER. 1999. Chloroplastic changes associated with paclobutrazol-induced protection in maize seedlings. Can.J. Bot.77(2): 279-290.

WANG, S.Y., J.K. BYUN,and G.L. STEFFENS. 1985. Controlling plant growth rate via the gibberellin biosynthesis II: Biochemical and physiological alterations in apple seedlings. Plant Physiol. 82:11-14. 
WIELAND, W.F. and R.L.WAMPLE. 1985. Root growth, water relations and mineral uptake of young 'Delicious' apple trees treated with soil- and stem-applied paclobutrazol.Sci. Hort.26(2):129-137

YELENOSKY, G., J.C.V. VU, and H.K. WUTCHER. 1995. Influence of paclobutrazol in the soil on growth, nutrient elements in the leaves and flood/freeze tolerance of citrus rootstocks seedlings. J. Plant Growth Regul. 14:129-134

YESHITELA, T.B. 2004. Paclobutrazol suppressed vegetative growth and improved yield as well as fruit quality of 'Tommy Atkins' mango (Mangiferaindica L) in Ethiopia. New Zealand Jour. of Crop and Horticultural Sci. 32(3).

ZHOU, W.J. and F. XI. 1993. Effects of mixtatol and paclobutrazol on photosynthesis and yield of rape (Brassica napus). Jour. of Plant Growth Regul.12:157-161.

http://abstracts.aspb.org/pb2003/public/P72/1437 